\title{
Interactions of cage aquaculture in Nile Delta lakes: Insights from field data and models
}

\author{
Daniele Brigolin $^{\mathrm{a}, *}$, Fabio Pranovi ${ }^{\mathrm{a}}$, Suzan Kholeif ${ }^{\mathrm{b}}$, Kahled Abdelsalam ${ }^{\mathrm{b}}$, \\ Roberto Pastres ${ }^{\text {a }}$ \\ a Department of Environmental Sciences, Informatics and Statistics, Ca'Foscari University of Venice, Dorsoduro 2137, 30123 Venice, Italy \\ ${ }^{\mathrm{b}}$ National Institute of Oceanography and Fishery, NIOF, Egypt
}

\section{A R T I C L E I N F O}

\section{Article history:}

Received 15 December 2015

Accepted 15 June 2016

Available online 18 June 2016

\section{Keywords:}

Fish cage culture

Aquaculture impact indicators

Lagrangian models

Sediment organic enrichment

Macrobenthos

Nile Delta lakes

\begin{abstract}
A B S T R A C T
In this paper, we present a cost-effective approach to the assessment of the impact of fish cage culture in transitional water bodies characterized by limited exchanges with the sea. The approach, previously applied to marine coastal areas, is based on two steps: (1) the application of a Lagrangian model, driven by purposely collected data concerning the local hydrodynamic, for an "a priori" simulation of the dispersion of uneaten feed and fecal material from a cage; (2) the collection of a set of field data concerning both water column and sediment indicators, sensitive to the release of organic matter from a cage, along a transect: the latter is determined on the basis of the results provided by the dispersion model. The methodology was tested at a seabass/seabream farm located in a coastal lake on the Nile Delta, namely Lake Maryut. Model results indicated that the area impacted by the cage is relatively small, about $5 \mathrm{~m}$ from the edge of the cage: this finding was later corroborated by field observations. As far as the water column is concerned, Dissolved Inorganic Nitrogen was found to be higher near the farm. The most sensitive sediment indicators were found to be surface sediment TOC, and benthic macrofauna abundances, which were, respectively, higher and lower in the proximity of the farm. These findings suggest that a cost-effective monitoring programme of the environmental impact of intensive aquaculture could be implemented in Egyptian coastal Lakes, thus providing a science-based support to the implementation of the ecosystem approach to aquaculture in these important ecosystems.
\end{abstract}

(C) 2016 Elsevier B.V. All rights reserved.

\section{Introduction}

Aquaculture has been rapidly increasing in Egypt in the last 30 years and, at present, contribute to about $70 \%$ of the total fish production, which reached the $1.110^{6}$ tonnes in 2009 (GAFRD, 2011). Semi-intensive fish farming in earthen ponds still represents, by far, the most important contribution to the total aquaculture production, but intensive cage culture is definitely on the rise. In fact, in the last twenty years, the production from fish cages has grown (El-Sayed, 2012), from 2103 tons in 1997 to 62276 tons in 2007 (GAFRD, 2007), and presently includes also marine species, such as European seabass, Dicentrarchus labrax (herein seabass) and Gilthead seabream Sparus aurata (herein seabream), besides the fresh/brackish water species traditionally farmed, i.e. tilapia, (Oreochromis niloticus), two mullet species, (Mugil cephalus, Liza ramada), and carps (Cyprinus carpio). In 2010, seabass and seabream

\footnotetext{
* Corresponding author. Fax: +39 0412348584.

E-mail address: brigo@unive.it (D. Brigolin).
}

production from fish cages reached 31,000 tons (GAFRD, 2011), which represented about $3 \%$ of the total Egyptian fish production.

A relevant fraction of seabass/seabream production is harvested in the four main coastal lakes located in the Nile Delta, i.e. Maryut, Edku, Burullus and Manzala. These ecosystems are still very productive ones, even though their environmental status is being threatened by several anthropogenic pressures. Fishery and aquaculture are regarded as main drivers and, according to (e.g. Shaltout, 2010), their impacts need to be assessed in order to implement a management strategy based on the Ecosystem Approach to Aquaculture (EAA), endorsed by FAO (Soto et al., 2008).

The impact of fish cage culture has been extensively studied both in coastal waters (Hargrave, 2010) and in tropical lake systems (Troell and Berg, 1997; Beveridge, 2008). However, thus far, they have not been assessed in Egyptian coastal lakes, where only the impact of farming of herbivorous/detritivorous species, mainly Nile tilapia and mullets, were investigated (El-Sayed, 2006).

Fish cages release in the surrounding both organic matter and dissolved nutrients: in the case of Nile Delta Lakes, their local 
Table 1

Husbandry practices at lake Maryut.

\begin{tabular}{|c|c|c|}
\hline Input & Value & Source \\
\hline Stocking density & 10 ind. $\mathrm{m}^{-3}$ & This study (Brigolin et al., 2013) \\
\hline Average stocking & $15 \mathrm{~g}$ & This study (Brigolin et al., 2013) \\
\hline
\end{tabular}

weight

Feed ration

Feed composition
Month 1

$10 \%$ of the fish biomass, on a daily basis

Month 2-4

$3 \%$ of the fish biomass, on a daily basis

Month 5-14

$0.6 \%$ of the fish biomass, on a daily basis

$40 \%$ proteins; $20 \%$ carbohydrates; $20 \%$ lipids
This study (Brigolin et al., 2013); Hamdi and Si Bachir (2011)

Proteins (Brigolin et al., 2013) carbohydrates and lipids were assumed on the basis of typical commercial fish feed composition data impact on both the water column and benthic ecosystems may concern a restricted area but be very relevant, due to high residence time and poor hydrodynamic circulation. For example, according to El-Adawy et al. (2013), the residence time is higher than 60 days in Lake Burullus western sector.

In general, the assimilative capacity of these ecosystems could be much lower than that of coastal marine ecosystems, in which cage culture is usually practiced. In turn, this means that stocking densities in Nile Delta Lakes should be kept at lower levels, compared with coastal waters, in order to avoid excessive impacts on their environmental status.

In this study, we investigated how the impact of seabass and seabream cages depends on local hydrodynamic and on husbandry practices in lake Maryut, in order to:

(1) identify a subset of indicators, to be used for Environmental Impact Assessment and monitoring also in the other coastal lakes;

(2) provide a preliminary assessment of the impact in relation to the stocking density, by means of a mathematical models which simulates the transport and fate of the organic matter released by a fish cage.

From the methodological point of view, the simulation model plays a key role, as it was used for: (1) designing the sampling of the indicators; (2) relating the impact to the stock density and husbandry practices.

\section{Study site and husbandry practices}

Lake Maryut is located about $20 \mathrm{~km}$ West from the city of Alexandria and covers a surface of $67 \mathrm{~km}^{2}$ (see Fig. 1). It receives runoff waters from the Nile delta, as well as wastewaters discharged by Alexandria and its industrial area. Water depth ranges between 0.4 and $2 \mathrm{~m}$ (EA Engineering, 1997), and the salinity is very low, ranging between 2 to 5 psu (EA Engineering, 1997). At present, artisanal fishery and aquaculture still play a relevant role in the local economy, even though Maryut total production is markedly lower than the one of other Egyptian coastal lakes (approximately $10 \%$ of the Manzala and Burullus ones Oczkowski and Nixon, 2008, Rahman, 2011).

In Lake Maryut, intensive seabass/seabream culture is usually practiced using $15 \mathrm{~m} \times 15 \mathrm{~m} \times 2 \mathrm{~m}$ square cages. Husbandry practices, which may slightly vary from farm to farm, are summarized in Table 1: they were determined by directly interviewing the farmers during the FORCE EU project (Brigolin et al., 2013). These data were then used as input for the FiCIM model, see next section. Juveniles are recruited from fishery, due to the lack of hatcheries, and stocked at a density of about 10-15 fingerlings $\mathrm{m}^{-3}$ in April-May (Brigolin et al., 2013). Local farmers use both commercial feed and trash fish, in order to minimize feeding costs. In particular, they supply commercial feeds during the first six months of the rearing cycle: afterwards, fish is fed with trash

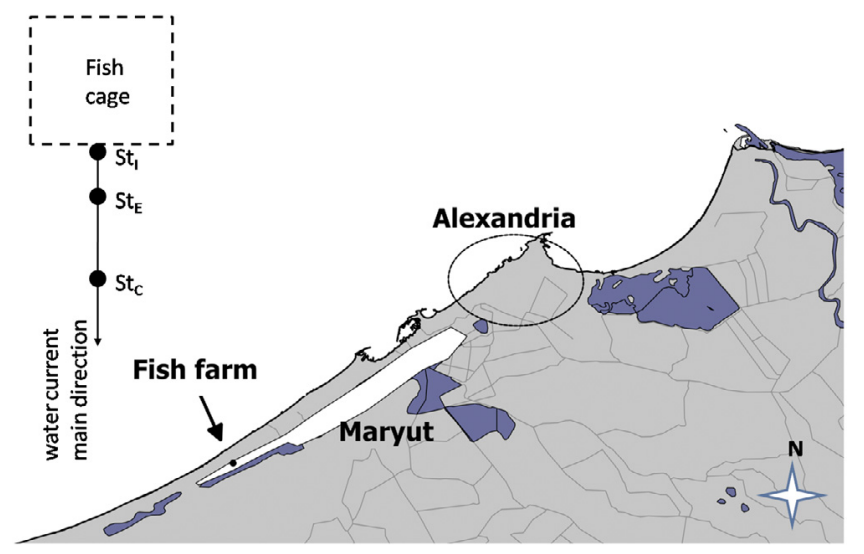

Fig. 1. Location of the Maryut coastal lake, and position of the fish farm. The figure shows a schematic representation of the sampling design adopted in this study: stations $\mathrm{st}_{\mathrm{I}}, \mathrm{st}_{\mathrm{E}}$ and $\mathrm{st}_{\mathrm{C}}$ were located along the major current axis.

fish, mainly sardines, green tilapia and, sometimes, cheap shrimp species (Brigolin et al., 2013). On average, a farming cycle last from 14 to 18 months: the seabream weight at harvest ranges from 350 to $450 \mathrm{~g}$ and that of seabass from 600 to $700 \mathrm{~g}$ (Brigolin et al., 2013).

\section{Materials \& methods}

The methodology here proposed was tested and previously applied in coastal areas in the framework of the ECASA EU project (e.g. Rampazzo et al., 2013; Brigolin et al., 2008). It involves three steps, namely:

(1) the collection of local hydrodynamic data;

(2) the use of a simulation model for estimating "a priori" the likely area of impact and, on this basis, designing the sampling program;

(3) the collection of biogeochemical and ecological data along a transect, in order to test the model findings and assess the environmental impact of a farm, on the basis of a set of candidate indicators.

The application of this approach to Lake Maryut required a thorough revision of the literature, in order to find a suitable set of candidate indicators, as well as several changes in the simulation model, as described in the following subsections.

\subsection{The simulation model}

The environmental impact related to the load of organic matter released by a fish farm on water column and sediment biogeochemistry as well as on the benthic community was assessed using the model FiCIM (Fish Cage Integrated Model), which is described in detail in Brigolin et al. (2014). The model is made up of three modules which enable one: (a) to simulate the evolution of wet weights of seabass/seabream individuals and their survival rates, in relation to the husbandry practices and water 
Table 2

Site-specific parameters, and forcing functions for the FiCIM model.

\begin{tabular}{|c|c|c|}
\hline Input parameters & Value & Source \\
\hline Water depth & $3 \mathrm{~m}$ & This study (Brigolin et al., 2013) \\
\hline Density of surface sediment & $2.5 \mathrm{~g} \mathrm{~cm}^{-3}$ & \\
\hline OM degradation rate & $10 \mathrm{y}^{-1}$ & Brigolin et al. (2009) \\
\hline \multicolumn{3}{|l|}{ Forcing functions } \\
\hline Daily water temperature & $\begin{array}{l}\text { Time series estimated by linearly interpolating monthly data } \\
\text { concerning Nile Delta lakes }\end{array}$ & (Shaltout and Khalil, 2005). \\
\hline Currents & See Fig. 4 & This study (Aanderaa-RCM7 current meter) \\
\hline
\end{tabular}

Table 3

Variables selected as indicators of farm interaction with the environment.

\begin{tabular}{llll}
\hline & Name & Unit & Abbreviation \\
\hline \multirow{3}{*}{ Water column } & TSM & $\left(\mathrm{g} \mathrm{L}^{-1}\right)$ & Total Suspended Matter \\
Chl-a & $\left(\mu \mathrm{g} \mathrm{L}^{-1}\right)$ & Chlorophyll-a \\
PON & $(\mu \mathrm{M})$ & Particulate Organic Nitrogen \\
POP & $(\mu \mathrm{M})$ & Particulate Organic Phosphorus \\
DIN & $(\mu \mathrm{M})$ & Dissolved Inorganic Nitrogen \\
DIP & $(\mu \mathrm{M})$ & Dissolved Inorganic Phosphorus \\
DON & $(\mu \mathrm{M})$ & Dissolved Organic Nitrogen \\
DOP & $(\mu \mathrm{M})$ & Dissolved Organic Phosphorus \\
Sediment & $(\%)$ & Water content \\
& TOC & $(\%)$ & Total Organic Carbon \\
& LOI & $(\%)$ & Loss on Ignition at 550 ${ }^{\circ} \mathrm{C}$ \\
& OP & $(\mu \mathrm{g} \mathrm{g})$ & Organic Phosphorus \\
& OC/OP & $(\mathrm{mol} / \mathrm{mol})$ & Carbon Phosphorus ratio
\end{tabular}

temperature and to estimate the daily fluxes of uneaten feed and feces released by a cage; (b) to simulate the dispersion of uneaten feed and fecal particles in the surrounding and their deposition on surface sediment; (c) to simulate subsequent organic carbon degradation by means of a first-order decay kinetic. The impact of a farm is obtained by adding up the impact of each single cage. As a result, the model allows one to predict the spatial distribution of the flux of Organic Carbon (OC) towards the sea bed as well as the increase in the concentration of $\mathrm{OC}$ in surface sediments due to the presence of a fish farm.

As part of this study, the code was adapted to simulate the processes outlined above in a brackish coastal lake, characterized by shallow waters. The main changes concerned the Lagrangian particle tracking module, which is based on the algorithm proposed by Jusup et al. (2007). The size of the horizontal computational grid was decreased down to $2 \mathrm{~m}$, and the integration time-step was consequently reduced to $30 \mathrm{~s}$, in order to ensure the stability of the numerical solution. The subset of input data concerning the husbandry practices is presented in Table 1: a complementary set of input data is summarized in Table 2 . We used the model for two purposes:

(1) a short, 4 month long run, from April 1st 2013 until the sampling day, July 1 st, was performed, aimed at assessing "a priori" the size of the impacted area;

(2) a long, 14 month long run, representative of an average farming cycle, was performed, aimed at estimating the impact of the farm on sediment biogeochemistry and benthic community. This was carried out with 10 and 40 ind. $\mathrm{m}^{-2}$ (this second value based on Halwart et al., 2007), in order to obtain a preliminary assessment of the impact of the farm in relation to the stocking density.

\subsection{Selection of the set of candidate impact indicators}

Water column candidate indicators, which included the 8 variables reported in Table 3, were selected in accordance with the results presented in the two meta-analysis carried out by Sarà (2007a,b). Sediment indicators were selected on the basis of the results by ECASA project (http://www.ecasatoolbox.org.uk) in which the effectiveness of different indicators in detecting impacts in low organic enrichment was investigated (also reported in Table 3).

Two water samples were collected at each station, by means of Niskin bottles, respectively in proximity of the surface and of the bottom. Chlorophyll-a, was determined according to the Strickland and Parsons (1972) methodology. TSM PON POP DIN DIP DON DOP were determined according to the procedures reported in the (ECASA book of protocols, 2008). At each sampling site, surface sediments were collected by means of an Ekman grab $(15 \times 15 \mathrm{~cm}$, $10 \mathrm{~cm}$ depth). Sediment cores about $5 \mathrm{~cm}$ long were sub-sampled in-situ from the Ekman grab using liners. In the laboratory, from each core the upper $1 \mathrm{~cm}$ thick slice was selected. Sample granulometry was determined according to Folk (1974). Samples containing $>90 \%$ of the fractions coarser than 4 phi were subjected to dry sieving, while the finer fraction was processed by pipette analysis. Loss on Ignition (LOI) was determined after drying the sample at $105^{\circ} \mathrm{C}$. The sample was weighed prior and after heating at $550{ }^{\circ} \mathrm{C}$ for $2.5 \mathrm{~h}$. Total organic carbon (TOC) content was determined by oxidation with $1 \mathrm{~N} \mathrm{~K}_{2} \mathrm{Cr}_{2} \mathrm{O}_{7}$ acidified with concentrated $\mathrm{H}_{2} \mathrm{SO}_{4}$ and titrate with $0.5 \mathrm{~N} \mathrm{Fe}\left(\mathrm{NH}^{4}\right)_{2}\left(\mathrm{SO}_{4}\right)_{2}$ (Loring and Rantala, 1992). The total phosphorus (TP) content was determined according to Aspila et al. (1976). The samples were ignited in muffle furnace at $550 \mathrm{C}$, and then extracted with $1 \mathrm{~N} \mathrm{HCl}$. The inorganic phosphorus (IP) was determined using the same method for TP, omitting ignition. Organic phosphorus (OP) was estimated by difference. Macrofauna was sampled by means of an Ekman grab $(15 \times 15 \mathrm{~cm})$. Six replicate were collected at each station, and sieved through a $500 \mu \mathrm{m}$ mesh. Samples were sorted into major taxa and specimens identified at the lower taxonomic level. Total macrofauna biomass (wet weight) was also determined per each sample ( g grab area $^{-1}$ ). AMBI (AZTI's Marine Biotic Index) (Borja et al., 2000, 2003) was calculated at each station, in order to provide a classification of the site based on benthic community status.

\subsection{Design of the sampling programme}

The sampling network was designed by combining the results of the statistical analysis of the current data with those obtained by the FiCIM short simulation. 


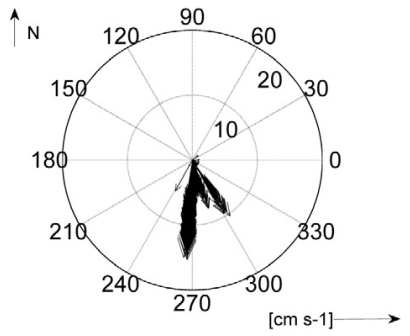

Fig. 2. Module and directions of the water currents, as measured at the farm site.

Current data were first collected at a sampling station located in lake Maryut approximately $150 \mathrm{~m}$ NE from the cage, using an Aanderaa-RCM7 current meter, which was deployed from May 6th to May 20th 2013 and kept at the depth of $1 \mathrm{~m}$.

An explorative analysis of the current time series allowed us to determine the main current direction, which was taken as the direction of the sampling transect. Three sampling stations were located along the transect at an increasing distance from the edge of the fish cage (see Fig. 1). Distance was defined based on model results and on two thresholds set a-priori. According to the works by Hargrave (2010) and Cromey et al. (1998) the area with C flux $(\Phi C)>0.1 \mathrm{gC} \mathrm{m}^{-2} \mathrm{~d}^{-1}$ is characterized as "moderately enriched". A control station, stC was therefore located outside the area with $(\Phi \mathrm{C})>0.1 \mathrm{gC} \mathrm{m}^{-2} \mathrm{~d}^{-1}$. Inside the deposition area two situations were distinguished: (i) a moderately enriched one $s_{\mathrm{E}}$; (ii) an impacted one, st $_{\mathrm{I}}$. According to Hyland et al. (2005) severe stress for benthic infauna occurs above 3.5\% TOC, value which was selected as a threshold for delimiting the "impacted area". In order to do this, a TOC value of $2.5 \%$ was taken as representative of a background condition for this confined portion of lake Maryut (Woronco, 2012).

At each site, the same set of indicators was collected. The current data were collected from May 6th to May 20th 2013 and the set of indicators were sampled in July 2013.

\section{Results}

\subsection{Design of the sampling survey}

As one can see from Fig. 2, the main direction of water currents is oriented S-SE. The average velocity module, computed over the whole time series, is $4.8 \mathrm{~cm} \mathrm{~s}^{-1}$ (st. dev. $\pm 2.7 \mathrm{~m} \mathrm{~s}^{-1}$; min-max range $0.003-15 \mathrm{~m} \mathrm{~s}^{-1}$ ). These values are in the lower end of the range characterizing Mediterranean fish farms located in sheltered environments (e.g. Holmer et al. (2008) reported average velocities comprised between 4.7 and $20.0 \mathrm{~cm} \mathrm{~s}^{-1}$ ).

Results from the deposition module are shown in Fig. 3(a), (b): due to the shallowness of the site, most of the organic matter accumulates in a restricted area around the cage. Along the SSE direction a flux of approximately $5 \mathrm{gC} \mathrm{m}^{-2}$ day $^{-1}$ is predicted by the model, up to a distance of $5 \mathrm{~m}$ form the edge of the cage (12.5 $\mathrm{m}$ from the center of the cage). The area of "moderate organic enrichment" $\left(\leq 0.1 \mathrm{gC} \mathrm{m}^{-2}\right.$ day $\left.^{-1}\right)$ extends up to $18 \mathrm{~m}$ from the edge of the cage. The intense flux of uneaten feed and feces causes an enhancement of OC concentrations in the upper sediment layer $(1 \mathrm{st} \mathrm{cm})$, reaching values as high as $2 \%$ in most of the area underneath the farm, and exceeding $1 \%$ up to a distance of $4 \mathrm{~m}$ (Fig. 3(b)). By summing this value to the background OC concentration (2.5\%), this area exceeded the 3.5\% OC and was identified as the "impacted area". Based on these model results stations $s t_{I}, s t_{E}$, and $s t_{C}$ were set along the $S$-SE direction, respectively at $0 \mathrm{~m}, 5 \mathrm{~m}$ and $25 \mathrm{~m}$ from the edge of the cage.
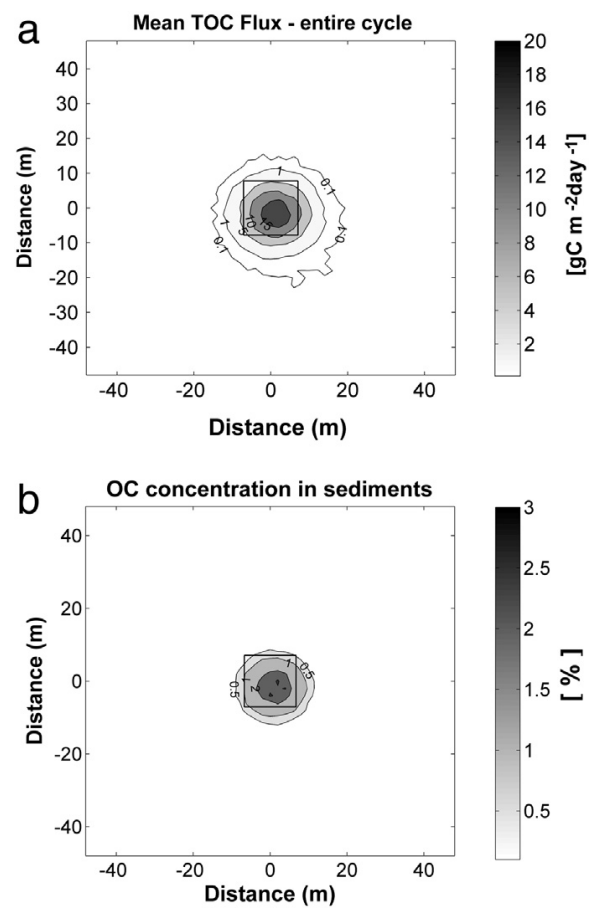

Fig. 3. (a, b) Results of the integrated aquaculture impact assessment model at 4 months from stocking. (a) Mean daily organic carbon flux $\left(\mathrm{gC} \mathrm{m}^{-2} \mathrm{~d}^{-1}\right)$; (b) modeled organic carbon concentration (\%) in the upper sediment.

\subsection{Water column, sediment geochemistry and macrofauna}

The data collected at the three sampling stations are reported in Tables 4 and 5. For sake of clarity, the following notation will be used here-in: $\mathrm{st}_{\mathrm{I}} \equiv \mathrm{st}_{0}, \mathrm{st}_{\mathrm{E}} \equiv \mathrm{st}_{5}$ and $\mathrm{st}_{\mathrm{C}} \equiv \mathrm{st}_{25}$. The visual inspection of DIN and TOC data suggested that remarkable differences are present among stations $\mathrm{st}_{0}, \mathrm{st}_{5}$, and station $\mathrm{st}_{25}$. DIN peaks at $\mathrm{st}_{5}$, mean value $=13.56 \mu \mathrm{M}, 2.3$ times higher than at $\mathrm{st}_{25}$. TOC reaches concentrations as high as $4.7 \%$ at the edge of the cage, $\mathrm{st}_{0}$, with a background value of $3.01 \%$ at $\mathrm{st}_{25}$.

\subsection{Macrofauna}

Fourteen taxa of benthic invertebrates were recorded at Maryut lake (for the complete list see Table 6).

In general, the number of taxa resulted to be similar in the three stations, as the diversity index values. The station $t_{0}$ showed the lowest values of abundance, whereas, in terms of total biomass, the lowest value was recorded in the station $t_{1}$. However, according to the AMBI index, all stations in Maryut were classified as "slightly disturbed" and presented a restricted variability in H diversity.

\subsection{Simulation scenarios}

Results from the long-term runs are presented in Fig. 4(a), (d). As one can see, average deposition over the entire cycle (Fig. 4(a)) is predicted to be lower than that observed during the initial 4 months, when the feeding regime is higher. This induces a restriction of the area identified as "degraded" (TOC > $>3.5 \%-$ considering a background value of $2.5 \%$ ), which is limited to a portion approximately equivalent to $1 / 4$ of the cage. The situation is reversed under the long-term scenario, considering an enhanced stocking density (40 ind. $\mathrm{m}^{-2}$ ). In this case, see Fig. 4(c), (d), the limits of the zone undergoing a "moderate organic enrichment" (TOC flux $>0.1 \mathrm{gC} \mathrm{m}^{-2} \mathrm{day}^{-1}$ ) are exceeding the $25 \mathrm{~m}$ from the edge of the cage, and TOC concentrations exceeding $5 \%$ are detected in almost all the area occupied by the cage. 
Table 4

Water column indicators: field data collected at the 3 stations in Lake Maryut.

\begin{tabular}{|c|c|c|c|c|c|c|c|c|}
\hline Dist. (m) & TSM (g/l) & Chl-a $(\mu \mathrm{g} / \mathrm{l})$ & PON $(\mu \mathrm{M})$ & $\mathrm{POP}(\mu \mathrm{M})$ & $\operatorname{DIN}(\mu \mathrm{M})$ & $\operatorname{DIP}(\mu \mathrm{M})$ & DON $(\mu \mathrm{M})$ & $\mathrm{DOP}(\mu \mathrm{M})$ \\
\hline $\mathrm{st}_{0}$ & 0.011 & 2.196 & 4.7 & 0.048 & 12.15 & 0.288 & 10.9 & 0.384 \\
\hline $\mathrm{st}_{0}$ & 0.015 & 1.992 & 4.35 & 0.06 & 5.66 & 0.288 & 13.92 & 0.372 \\
\hline $\mathrm{st}_{5}$ & 0.007 & 2.141 & 4.33 & 0.096 & 13.3 & 0.192 & 18.28 & 0.336 \\
\hline $\mathrm{st}_{5}$ & 0.012 & 2.015 & 3.48 & 0.432 & 13.82 & 0.096 & 15.3 & 0.288 \\
\hline $\mathrm{st}_{25}$ & 0.01 & 2.077 & 7.48 & 0.288 & 7.64 & 0.096 & 13.46 & 0.48 \\
\hline $\mathrm{st}_{25}$ & 0.019 & 1.981 & 7.23 & 0.384 & 4.24 & 0.336 & 14.56 & 0.192 \\
\hline
\end{tabular}

Table 5

Sediment indicators: field data collected at the 3 stations sampled in Lake Maryut.

\begin{tabular}{|c|c|c|c|c|}
\hline Water content (\%) & Total organic carbon (\%) & Loss on ignition at $550{ }^{\circ} \mathrm{C}(\%)$ & $\mathrm{OP}\left(\mu \mathrm{gg}^{-1}\right)$ & $\mathrm{OC} / \mathrm{OP}(\mathrm{mol} / \mathrm{mol})$ \\
\hline $0 \mathrm{~m}=67$ & $0 \mathrm{~m}=4.70$ & $0 \mathrm{~m}=16.79$ & $0 \mathrm{~m}=136$ & $0 \mathrm{~m}=892$ \\
\hline $5 \mathrm{~m}=59$ & $5 \mathrm{~m}=3.14$ & $5 \mathrm{~m}=12.24$ & $5 \mathrm{~m}=130$ & $5 \mathrm{~m}=625$ \\
\hline $25 \mathrm{~m}=56$ & $25 \mathrm{~m}=3.01$ & $25 \mathrm{~m}=9.89$ & $25 \mathrm{~m}=143$ & $25 \mathrm{~m}=543$ \\
\hline
\end{tabular}

Table 6

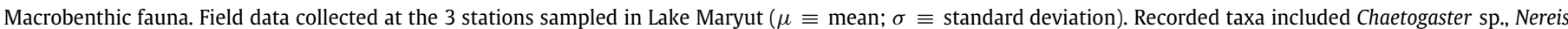

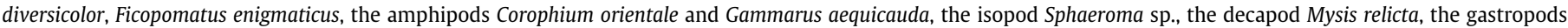

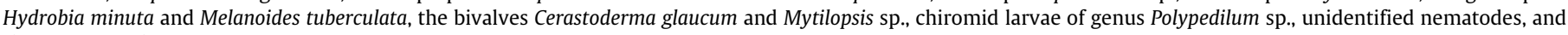
the encrusting bryozoan Conopeum sp.

\begin{tabular}{|c|c|c|c|c|c|c|c|c|c|c|}
\hline \multirow[t]{2}{*}{ Station } & \multicolumn{2}{|c|}{ Total abundance } & \multicolumn{2}{|c|}{ Total biomass (g ww) } & \multicolumn{2}{|c|}{ Number of taxa } & \multicolumn{2}{|c|}{ Diversity index $(\mathrm{H})$} & \multicolumn{2}{|l|}{ AMBI } \\
\hline & $\mu$ & $\sigma$ & $\mu$ & $\sigma$ & $\mu$ & $\sigma$ & $\mu$ & $\sigma$ & Value & Disturbance classification \\
\hline $\mathrm{st}_{0}$ & 175.5 & 29.13 & 7.56 & 2.48 & 11.2 & 1.1 & 1.89 & 0.1 & 2.758 & Slightly disturbed \\
\hline $\mathrm{st}_{5}$ & 429.8 & 62.8 & 3.0 & 0.9 & 10.3 & 1.0 & 1.3 & 0.1 & 2.657 & Slightly disturbed \\
\hline $\mathrm{st}_{25}$ & 358.3 & 136.0 & 16.5 & 9.3 & 10.7 & 0.8 & 1.8 & 0.2 & 2.876 & Slightly disturbed \\
\hline
\end{tabular}

a
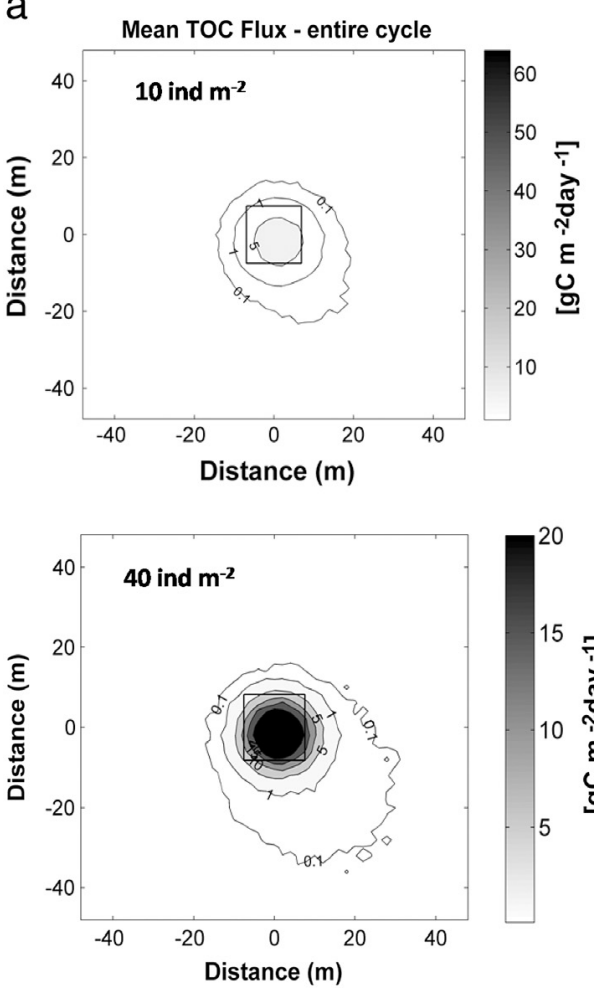

b OC concentration in sediments
- entire cycle

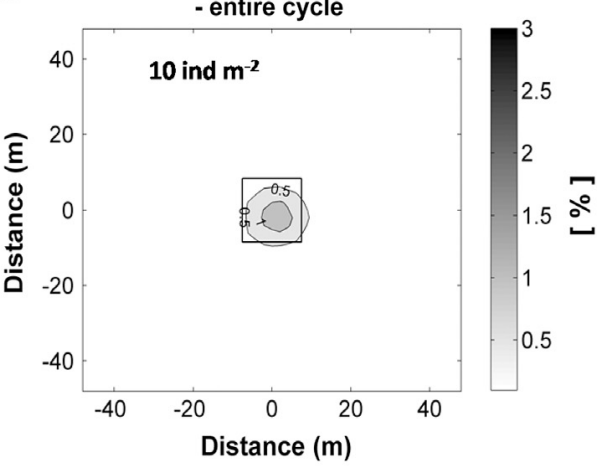

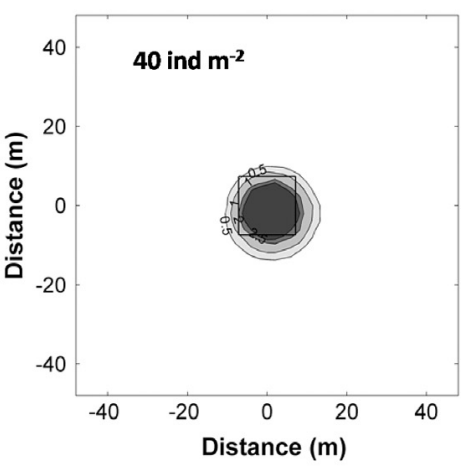

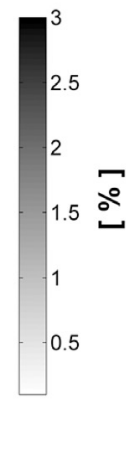

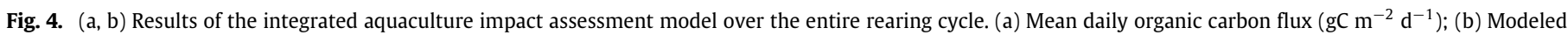
organic carbon concentration (\%) in the upper sediment.

\section{Discussion}

Starting from a set of indicators designed to assess the impacts of aquaculture in marine coastal areas, this work allowed us to identify the subset of indicators which performs better in a shallow water transitional environment characterized by a limited exchange with the sea. These are water column DIN, TOC in surface sediments, and macrobenthos abundance, all presenting higher values nearby the fish cage. As far as dissolved nutrients is concerned (NH4, NO2, NO3, PO4, SiO2), finfish aquaculture (marine/brackish water species) is expected to impact mainly on $\mathrm{NH} 4$, NO2 (Sarà, 2007b). Our results confirmed this trend, indicating an higher sensitivity of DIN with respect to DIP. However, although in presence of low water currents, enhanced DIN concentrations 
seem to have a limited role in stimulating phytoplankton productivity in Maryut, and CHL-a values are kept at relatively low values for a transitional water body $\left(2.1 \mu \mathrm{g} \mathrm{L}^{-1}\right.$ on average), presenting no substantial difference among the three sites.

A higher sensitivity to the presence of the farm was expected from the benthic indicators: this was clearly visible from a set of comparative experiments carried out at 10 European farms in the framework of ECASA project (see http://www.ecasatoolbox. org.uk). The meta-analysis carried out by Hyland et al. (2005), based on data obtained from 951 stations from 7 coastal regions on 3 different continents, reported that no stress for infaunal communities is commonly associated with TOC concentrations $<1 \%$, while severe stress is associated with TOC concentrations $>3.5 \%$. A question of relevance is whether, in an enclosed system such as lake Maryut, which is characterized by high organic matter sedimentation and an elevated level of background TOC $\left(\mathrm{st}_{25}=3.01 \%\right)$, the TOC enrichment induced by the fish cage causes relevant changes in the macrobenthic community structure. With reference to total abundance and biomass, the observed pattern resulted to be only partially in accordance with the results obtained in most of the ECASA sites (see Borja et al., 2009), with the highest biomass value recorded far from the cage, but the lower value, combined with the highest abundance, was recorded in the intermediate station. However, according to our results, a decreasing trend in macrobenthos abundances was detected from $\mathrm{st}_{25}$ to $\mathrm{st}_{0}$. The comparative study by Borja et al. (2009) also pointed out that peaks in total biomass were not aligned with those in total abundance, in agreement with our results (higher biomass at $\mathrm{st}_{0}$, compared to $\mathrm{st}_{5}$ ).

All this would be confirmed also by analysis of the community composition. Obtained results showed a substantial homogeneity of the macrobenthic community, as highlighted by the Shannon index and the AMBI (classifying all sites as "slightly disturbed"). This would be related to a community adapted to local 'selective' conditions, for which the contribute due to the cages resulted to be not so influent.

Model application allowed a preliminary characterization of the "zone of effect" (AZE) (according to GFCM definition, AZE is "the area that can be influenced by the farm and in which the monitoring activities should be done" GFCM, 2012). In this way, model results complemented the current meter data, and helped locating stations for monitoring. These model results were corroborated by field observation, which reported an increase in TOC concentrations of $1.6 \%$ between $\mathrm{st}_{5}$ and $\mathrm{st}_{0}$, with this latter one exceeding the $3.5 \%$. It is worth remarking here that results presented in Section 4.1 focused on the first 4 months of the farming cycle, in which feed conversion rate (FCR-weight of feed provided to weight of fish harvested) is expected to be higher with respect to the subsequent fattening period, but farmed biomass accounts for approximately $17 \%$ of the final stock at harvesting (111 kg over the final $650 \mathrm{~kg}$ ). With respect to this, results of the long-term run (Section 4.4), can provide additional information to regulators for planning the monitoring and locating stations $s t_{I}, s t_{M}$ and $s t_{C}$. Remarkably, the overall farm impact along the entire 14 months cycle was predicted to be lower than that observed during the first 4 months. This result was obtained under the hypothesis that feed quantity is reduced to $0.6 \%$ of the stocked biomass, on a daily basis, corresponding to an FCR of approximately 1.9. Unfortunately, no data were available for this, and the feed conversion value had to be set based on literature information for intense farming of the same species, at the same latitude (Hamdi and Si Bachir, 2011). We remark here that the extensive use of trash fish as feed, which was reported from the farmers to be a common practice in Maryut, could remarkably increase the value of this husbandry parameter, thus bringing to different estimations of the impacts of the farm along the entire cycle. To this regard, a precautionary principle should be taken into consideration, since sediment data indicate that, due to low flushing, organic matter sedimentation is markedly enhanced by the presence of cages. In hypertrophic regimes, such as those experienced by Egyptian coastal lakes (Oczkowski and Nixon, 2008), early diagenesis processes, involved in the mineralization of the highly degradable organic matter originated from the cage, could induce local hypoxic conditions. Besides being a major threat for the health of stocked fish (Oliva-Teles, 2012), persistent low oxygen concentrations can induce negative feedbacks at ecosystem level, e.g. altering functions of bio-irrigating and bioturbating macrofauna (for a review on the potential feedbacks see Middelburg and Levin, 2009), which, in turn, help in spreading hypoxic conditions around the area directly affected by farm deposition. An indication of the farmers awareness about this mechanism could be represented by the fact that fish are stocked at low densities, approximately $25 \%$ of the density used in suspended coastal cages (10 ind $\mathrm{m}^{-3}$ against 40 ind. $\mathrm{m}^{-3}$ ) (Halwart et al., 2007). In this framework, the approach followed in the second long-term run can be useful for farmers, in order to estimate expected impacts in response to an enhanced stocking density. To this regard, the simulation can be further extended by including the prediction of oxygen and sulphides dynamics (see Brigolin et al., 2009). In order to be performed, this step will require gathering the additional in-situ data necessary to validate the diagenesis model.

\section{Conclusions}

Results showed that the impact of the fish cage in lake Maryut is limited to a radius of $<5 \mathrm{~m}$ from the edge of the cage. Higher values of water column DIN were detected within this area, with respect to the control station, located at $25 \mathrm{~m}$ distance from the edge of the cage along the major current axis. An higher TOC and lower macrofaunal abundances were also recorded in the proximity of the farm.

This study allowed us to derive useful indications to optimize the sampling effort for a cost-effective environmental impact assessment in transitional water bodies characterized by limited exchanges with the sea: (i) it allowed the identification of the subset of most sensitive impact indicators; (ii) it illustrated the potential use of a simulation model for designing the sampling of the indicators and relating the impact to the stock density and husbandry practices.

Although oxygen monitoring is not currently in-place at Maryut farms, oxygen levels should be regarded as an issue of primary relevance at this site, in order to prevent loss of biomass.

These results go in the direction of defining monitoring methodologies complying with the principles of the ecosystem approach to aquaculture.

\section{Acknowledgments}

This work has been supported by EU Projects No. 295004 "Fisheries \& aquaculture Oriented Research Capacity in Egypt" (FORCE), and No. 282977 "Marine Ecosystem Dynamics and Indicators for North Africa” (MEDINA).

\section{References}

Aspila, K.I., Agemian, H., Chau, A.S.Y., 1976. A semiautomated method for the determination of inorganic, organic and total phosphate in sediments. Analyst 101, 187-197.

Beveridge, M., 2008. Cage Aquaculture. John Wiley \& Sons, p. 376.

Borja, A., Franco, J., Pérez, V., 2000. A marine biotic index to establish the ecological quality of soft-bottom benthos within European estuarine and coastal environments. Mar. Pollut. Bull. 40, 1100-1114. 
Borja, A., Muxika, I., Franco, J., 2003. The application of a Marine Biotic Index to different impact sources affecting soft-bottom benthic communities along European coasts. Mar. Pollut. Bull. 46, 835-845.

Borja, A., Germán Rodríguez, J., Black, K., Bodoy, A., Emblow, C., Fernandes, T.F., Forte, J., Karakassis, I., Muxika, I., Nickell, T.D., Papageorgiou, N., Pranovi, F. Sevastou, K., Tomassetti, P., Angel, D., 2009. Assessing the suitability of a range of benthic indices in the evaluation of environmental impact of fin and shellfish aquaculture located in sites across Europe. Aquaculture 293, 231-240.

Brigolin, D., Davydov, A., Pastres, R., Petrenko, I., 2008. Optimization of shellfish production carrying capacity at a farm scale. Appl. Math. Comput. 204, 532-540. http://dx.doi.org/10.1016/j.amc.2008.05.118.

Brigolin, D., Meccia, V.L., Venier, C., Tomassetti, P., Porrello, S., Pastres, R. 2014. Modelling the interactions between offshore fish cages and elemental biogeochemical cycles in the Mediterranean sea. Aquacult. Environ. Interact. 5 71-88.

Brigolin, D., Pastres, R., Nickell, T.D., Cromey, C.J., Aguilera, D.R., Regnier, P., 2009 Modelling the impact of aquaculture on early diagenetic processes in sea loch sediments. Mar. Ecol. Prog. Ser. 388, 63-80.

Brigolin, D., Pranovi, F., Venier, C., Pastres, R., 2013. Force D2.3. Technical report concerning selected case studies. INCO. 2011- 6.2 Fisheries \& aquaculture Oriented Research Capacity in Egypt. FP7 Coordination and support actionContract no. 295004, 37.

Cromey, C.J., Black, K.D., Edwards, A., Jack, I.A., 1998. Modelling the deposition and biological effects of organic carbon from marine sewage discharges. Estuar. Coast. Shelf Sci. 47, 295-308

EA Engineering, 1997. Science and Technology, Inc. Environmental Technica Report 8 Chemical and Biological Characterization of Lake Maryout, Fina Report. Alexandria Wastewater Project Phase II. USAID Project No. 263-0100. Prepared for Metcalf \& Eddy International, Roushdie, Alexandria, Prepared by EA Engineering, Science, and Technology, Inc., 26 Kordahy Street, Roushdie, Alexandria, Arab Republic of Egypt, May 28, 1997.

ECASA book of protocols, 2008. http://www.ecasatoolbox.org.uk/the-toolbox/eiacountry/book-of-protocols/book-of-protocols-introduction (last accessed 03.03.15).

El-Adawy, A., Negm, A.M., Elzeir, M.A., Saavedra, O.C., El-Shinnawy, I.A., Nadaoka, K., 2013. Modeling the Hydrodynamics and Salinity of El-Burullus Lake (Nile Delta, Northern Egypt). J. Clean Energy Technol. 1, 157-163.

El-Sayed, A.F., 2006. Tilapia Culture. CABI Publishing, p. 277.

El-Sayed, A.F., 2012. Force D2.1. Aquaculture in Egypt: state of the art. INCO 2011- 6.2 Fisheries \& aquaculture Oriented Research Capacity in Egypt. FP7 Coordination and support action-Contract no. 295004, 57.

Folk, R.L., 1974. The Petrology of Sedimentary Rocks. Hemplhill Publishing Company, p. 190.

GAFRD-General Authority for Fish Resources Development (GAFRD), 2007. Fish Production Statistics. Changes in fish production 1993-2007. GAFRD, Ministry of Agriculture and Land Reclamation. Available at http://kenanaonline.com/users/ StatisticsEN/downloads/19988 (last accessed 16.03.2015).

GAFRD-General Authority for Fisheries Resources Development (GAFRD), 2011 Fish Statistics Book 2010. Ministry of Agriculture and land Reclamation.

GFCM, 2012. (General Fisheries Commission for the Mediterranean) (2012) Report of the WGSC-ShoCMed Workshop on the definition and environmenta monitoring within Allowable Zone of Effect (AZE) of aquaculture activities within the Mediterranean countries. FAO, Rome.

Halwart, M., Soto, D., Arthur, J.R., 2007. Cage Aquaculture: Regional Reviews and Global Overview. FAO, Rome.
Hamdi, M.S., Si Bachir, M.A., 2011. Contribution? a l'elevage de la Daurade (Sparus aurata) en eau rechauffee: Cas de la ferme ONDPA Cap Djinet (wilaya deBoumerdes). Memoire de fin d'etudes en vue de l'obtention du diplome d'ingenieur d'etat en sciences de la mer, Enssmal, 105.

Hargrave, B.T., 2010. Empirical relationships describing benthic impacts of salmon aquaculture. Aquacult. Environ. Interact. 1, 33-46.

Holmer, M., Argyrou, M., Dalsgaard, T., Danovaro, R., Diaz-Almela, E., Duarte, C.M., Frederiksen, M., Grau, A., Karakassis, I., Marba, N., Mirto, S., Perez, M., Pusceddu, A., Tsapakis, M., 2008. Effects of fish farmwaste on Posidonia oceanica meadows: synthesis and provision of monitoring and management tools. Mar. Pollut. Bull. 56, 1618-1629.

Hyland, J., Balthis, L., Karakassis, I., Magni, P., et al., 2005. Organic carbon content of sediments as an indicator of stress in the marine benthos. Mar. Ecol. Progr. Ser. 295, 91-103.

Jusup, M., Gecek, S., Legovi, T., 2007. Impact of aquacultures on the marine ecosystem: modelling benthic carbon loading over variable depth. Ecol. Modell. 200, 459-466.

Loring, D.H., Rantala, R.T.T., 1992. Manual for the geochemical analyses of marine sediments and suspended particulate matter. Earth-Sci. Rev. 32, 235-283.

Middelburg, J.J., Levin, L.A., 2009. Coastal hypoxia and sediment biogeochemistry. Biogeosciences 6, 1273-1293.

Oczkowski, A., Nixon, S., 2008. Increasing nutrient concentrations and the rise and fall of a coastal fishery; a review of data from the Nile Delta, Egypt. Estuar. Coast. Shelf Sci. 77, 309-319.

Oliva-Teles, A., 2012. Nutrition and health of aquaculture fish. J. Fish Dis. 35, 83-108.

Rahman, S.H.A., 2011. Egypt country report. Meeting on Mediterranean coastal lagoons management: interactions between aquaculture and fisheries. Cagliari, Italy, 28-30 June 2011.

Rampazzo, F., Berto, D., Giani, M., Brigolin, D., Covelli, S., Cacciatore, F., Boscolo Brusà, R., Bellucci, L.G., Pastres, R., 2013. Impact of mussel farming on sedimentary geochemical properties of a Northern Adriatic area influenced by freshwater inflows. Estuar. Coast. Shelf Sci. 129, 49-58.

Sarà, G., 2007a. Ecological effects of aquaculture on living and non-living suspended fractions of the water column: A meta-analysis. Water Res. 41, 3187-3200.

Sarà, G., 2007b. A meta-analysis on the ecological effects of aquaculture on the water column: Dissolved nutrients. Mar. Environ. Res. 63, 390-408.

Shaltout, K.H., 2010. Towards mainstreaming Lake Burullus biodiversity, North Egypt (a review article). Ass. Univ. Bull. Environ. Res. 13, 71-87.

Shaltout, K.H., Khalil, M.T., 2005. Lake Burullus: Burullus Protected Area. Publication of National Biodiversity Unit. No. 13.

Soto, D., Aguilar-Manjarrez, J., Brugère, C., Angel, D., Bailey, C., Black, K., Edwards, P., Costa-Pierce, B., Chopin, T. Deudero, S., Freeman, S., Hambrey, J., Hishamunda, N., Knowler, D., Silvert, W., Marba, N., Mathe, S., Norambuena, R., Simard, F. Tett, P., Troell, M., Wainberg, A., 2008. Applying an ecosystem-based approach to aquaculture: principles, scales and some management measures. In D. Soto, J. Aguilar Manjarrez \& N. Hishamunda, eds. Building an ecosystem approach to aquaculture. FAO/Universitat de les Illes Balears Expert Workshop. 7-11 May 2007, Palma de Mallorca, Spain, 15-35. FAO Fisheries and Aquaculture Proceedings No. 14. Rome, FAO.

Strickland, J.D.H., Parsons, T.R., 1972. Practical Handbook of Seawater Analysis, second ed. Bulletin of the fisheries research board of Canada, pp. 167-310.

Troell, M., Berg, H., 1997. Cage fish farming in the tropical lake Kariba, Zimbabwe: impact and biogeochemical changes in the sediment. Aquacult. Res. 28, 527-544.

Woronco, B., 2012. Late-Holocene dust accumulation within the ancient town of Marea (coastal zone of the South Mediterranean Sea, N Egypt). Quat. Int. 266, 4-13. 